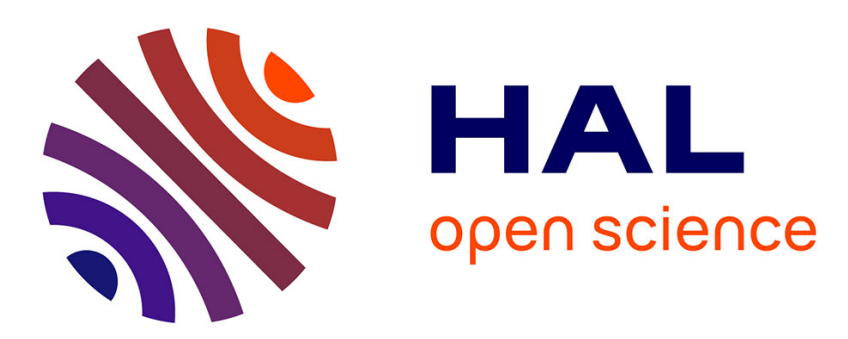

\title{
Characterization of the basement / cover unconformity based on Saint Pierre Bois quarry observations (Rhine Graben, France)
}

Chrystel Dezayes, Catherine Lerouge, Philippe Lach

\section{- To cite this version: \\ Chrystel Dezayes, Catherine Lerouge, Philippe Lach. Characterization of the basement / cover uncon- formity based on Saint Pierre Bois quarry observations (Rhine Graben, France). EAGE - GET2020 - Online, Nov 2020, Strasbourg, France. hal-02928356}

\section{HAL Id: hal-02928356 https: / hal-brgm.archives-ouvertes.fr/hal-02928356}

Submitted on 2 Sep 2020

HAL is a multi-disciplinary open access archive for the deposit and dissemination of scientific research documents, whether they are published or not. The documents may come from teaching and research institutions in France or abroad, or from public or private research centers.
L'archive ouverte pluridisciplinaire HAL, est destinée au dépôt et à la diffusion de documents scientifiques de niveau recherche, publiés ou non, émanant des établissements d'enseignement et de recherche français ou étrangers, des laboratoires publics ou privés. 


\section{Introduction}

According to the literature, deep geothermal energy reserves are associated with naturally fractured/faulted reservoirs in various geological terrains. Fractures and faults provide pathways for fluid flow, which are crucial when primary porosity is low, such as in granite. Faults may be more permeable than fractures, but the fracture network may provide a more porous system than the former. Even though fractured reservoirs have been investigated for more than fifty years, it is difficult to model reservoir behavior because we lack knowledge of the fracture network efficient for fluid flow generally due to complex structural/tectonic history and episodic water/rock interactions associated with this history.

In this abstract, we present a combined works of structural and mineralogical analyses of the transition zone between the crystalline basement and its sedimentary cover. This zone is around $3 \mathrm{~km}$ within the Rhine Graben and constitute a target for deep geothermal energy with a reached temperature between $150^{\circ} \mathrm{C}$ and $180^{\circ} \mathrm{C}$, such as at Landau and Insheim in Germany, and at Soultz and Rittershoffen in France.

This characterization of the basement/sedimentary transition zone was performed at the Saint Pierre Bois quarry (Vosges, France), located on the western shoulder of the Rhine graben, in Central Vosges. The aim of this work is to define the major parameters that control the efficiency of a fracture network for fluid flow, based on:

- Description of the fracture network including fracture orientation measurements, fracture density, fracture distribution, microstructures, and deformation style, fracture filling,

- Chronology of cementation,

- Study of porosity and water/rock interactions at the fracture/fault scale.

The Saint Pierre Bois quarry is of particular interest for its contrasts in weathering, deformation, and rheology, and for three benches created by aggregate exploitation that provide a 3D picture of the fracture network in both granite and the Stephanian sedimentary cover, and of connectivity between them. The Hercynian granite belongs to the generation of two mica leucogranite emplaced along major crustal accidents during the late Carboniferous in the Central Vosges, 322-330 Ma ago. By measuring fractures and characterizing wall rock alteration and mineral filling, we are able to propose a conceptual model of the quarry-scale fracture network that integrates fluid circulation with geological time.

\section{Methods}

To characterize a fracture network, several key parameters are needed: fracture orientation (strike and dip), fracture distribution, aperture (open, filling), mineral filling, length (extent, height) and connectivity (abutment, cross-cut, termination). As is commonly done, we used the scanline method to describe the fracture network in the quarry and performed a statistical analysis of special distribution. A total of 229 fracture orientations were measured on all the walls of the quarry, mainly in the granite, which is more accessible.

Infills of fractures were sampled in relation to their orientation and a petrological characterization was performed by optical microscopy and complementary scanning electron microscope.

Porosity data was acquired for granite and sandstone matrix in the Saint Pierre Bois by Kushnir et al., (2018) and was completed by measurement of the infill fractures. Four techniques were applied to different sample types: triple-weighing method, mercury porosimetry, helium pycnometry and digital image processing applied to back-scattered electron. 


\section{Results}

For all scanline directions measured in granite, the fracture patterns are equivalent in terms of orientation, whereas the density of each set varies. This suggests that our sampling is appropriate and avoids a high sampling bias. Two main/primary sets have been identified: F1, $\mathrm{N} 90^{\circ} \mathrm{E} \pm 20^{\circ}$ nearly vertical and $\mathrm{F} 2, \mathrm{~N} 30^{\circ} \mathrm{E} \pm 20^{\circ}$ dipping $55^{\circ}$ to SE. Fractures that do not belong to these sets are grouped in the F3 set, $\mathrm{N} 150^{\circ} \mathrm{E} \pm 40^{\circ}$.

Fracture frequency is approximately $0.7 \pm 0.07 \mathrm{fr} / \mathrm{m}$ and the most common spacing more than $1 \mathrm{~m}$, except for UW250 scanline, which shows a higher fracture frequency, approximately $1 \mathrm{fr} / \mathrm{m}$ and a primary spacing less than $1 \mathrm{~m}$. Whereas the coefficient of variation indicates a random fracture distribution, fracture clusters are identified (Figure 1).

Granite samples collected along major E-W tectonic corridors consist of cohesive cataclasite and breccia. Microquartz is the major cement in cohesive cataclastic zones in association with micron sized iron hydroxides and minor clay minerals. Clay minerals consist of illite, essentially, whose origin remains unknown. The same cements are present in the breccia; however, additional medium size subeuhedral to euhedral quartz grains also fill residual porosity. Rare macroscopic barite crystals (0.1 to $1.5 \mathrm{~cm}$ ) are associated with euhedral quartz-filled fractures. At the scale of the quarry, reddish or white/greenish coatings are present on numerous fault/fracture surfaces where striations are occasional present. These coatings are a $\mathrm{mm}$ - to $\mathrm{cm}$ - thick cohesive cataclasite of granite cemented by silica/microquartz. White/greenish/reddish colors are mainly due to the absence/presence of iron hydroxides.

Throughout the quarry, granite wall rock alteration due to fluid circulation through fractures/faults rapidly decreases within several centimeters. In the highly weathered-fractured zone, the high fracture density induces a large volume of altered granite matrix. Close to the fractures and faults and in the fault corridor, biotite and in lesser amounts, muscovite are altered to clay minerals (illite, illite-smectite mixed layers) with titanium oxides and iron hydroxides, K-feldspar is partially dissolved, and primary plagioclase is replaced by illite with $\mu$ m-sized aluminum-phosphate-sulfate (APS) minerals.

Porosities of breccias and cataclasites sampled in the structures range from 1.65 to $7.45 \%$. The lowest porosity values were measured in cataclasites. Porosity values of the bulk granite matrix in the core of the breccia corridors are rather low, whereas samples collected on the margins of a breccia corridor have bulk water porosities of 4.50 and $7.45 \%$. In the cohesive cataclasite, reddish zone cemented by iron hydroxides has He porosity of $6.74 \%$, whereas highly cohesive orange zone cemented by silica/microquartz has He porosity of $2.13 \%$.

The well in-place sedimentary cover overlying granite is accessible only in the northern part of the quarry and even there it is not easily accessible. Therefore, only 9 fracture orientations were measured, which does not constitute an adequate sample for statistics but does represent the overall orientation. The primary set is $\mathrm{N} 10^{\circ} \mathrm{E} \pm 10^{\circ}$ and the secondary set is $\mathrm{N} 100^{\circ} \mathrm{E} \pm 10^{\circ}$, all are nearly vertical.

Sedimentary cover consists of heterogranular medium to coarse-grained arkoses. Detrital minerals consist mainly of quartz, plagioclase, and K-feldspar grains, with minor micas, clay matrix, iron hydroxides, and heavy minerals. Feldspars, and more specifically plagioclase, exhibit a variable degree of dissolution. Authigenic minerals are primarily quartz with minor K-feldspar, clay minerals including illite, aluminum-phosphate-sulfate (APS) minerals, galena and pyrite. APS and illite essentially fill porosity of plagioclase dissolution. A generation of micron- to medium-grained quartz crystallized at sandstone grain contacts indicates a protocataclastic deformation in the weathered-fractured zone in the eastern part of the quarry. 
Bulk porosity and dissolution porosity of both types of feldspars measured in arkoses range between $~ 5$ and $14 \%$. Total porosity is relatively well correlated with grain size. In all cases, plagioclase dissolution porosity is significantly higher than $\mathrm{K}$ feldspar dissolution porosity.

\section{Discussion}

The study area is located in a highly fractured region affected by Hercynian tectonics and the Tertiary opening of the Rhine Graben. Whereas the main directions are equivalent in the Saint Pierre Bois quarry than in the all scales in the Rhine graben and its surrounding, the distributions of each set are different in the Vosges Massif and in the Rhine Graben. The Hercynian directions, mainly NE-SW and NW-SE, are more common than the Rhenish direction in the Vosges Massif. However, the E-W direction, which is mainly present in the Saint Pierre Bois quarry and its surroundings, is less frequent at the Rhine graben scale. This fracture set could be related to Hercynian tectonics and linked to the direction of the Villé basin, which opened during the Permian at the end of the Hercynian orogen.

Inside the quarry, two areas have been differentiated: the fractured-weathered zone to the east and a more structured zone in the western and northern parts (Figure 1). These zones are part of a larger fault zone, and are defined as the core zone and damage zone, respectively (Bauer et al., 2015). The damage zone includes three dominant fracture directions, sometimes grouped in clusters. This fracture sets can be linked to the Riedel model. Therefore, we consider the F1 fracture set $\left(\mathrm{N} 90^{\circ} \mathrm{E} \pm 20^{\circ}\right)$ to correspond to shear fracture in the R-direction. Likewise, the $\mathrm{F} 2$ fracture set $\left(\mathrm{N} 30^{\circ} \mathrm{E} \pm 20^{\circ}\right)$ corresponds to $\mathrm{P}$ ' fractures and the $\mathrm{F} 3$ fracture set $\left(\mathrm{N} 150^{\circ} \mathrm{E} \pm 40^{\circ}\right)$ to $\mathrm{P}$ fractures. This implies that the large fault zone should have a $\mathrm{N} 80^{\circ} \mathrm{E}$ direction with dextral motion during its formation in an ESE-WNW $\sigma_{1}$ stress field (Figure 1).

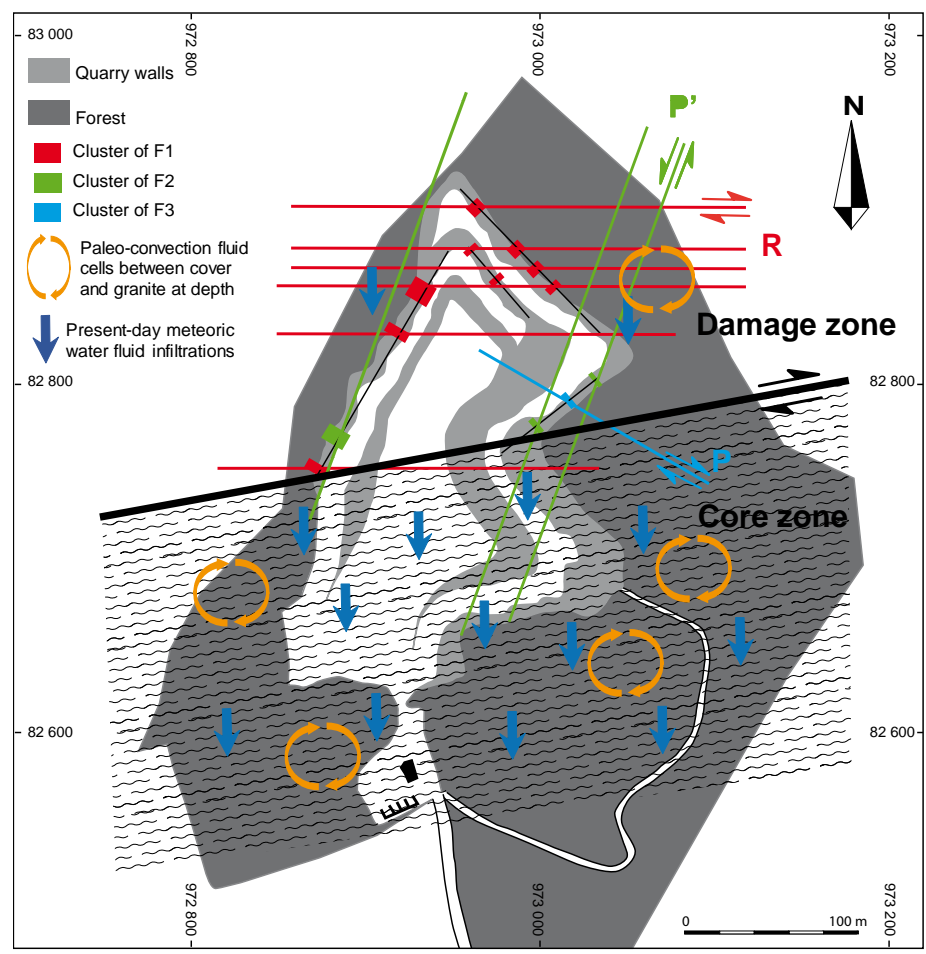

Figure 1 Main fracture direction in the Saint Pierre Bois quarry. The color rectangles on the wall represent the fracture clusters identified by the scanline analysis. Red: F1 set; green: F2 set; blue: F3 set. The large hatched sector represents the altered-fractured part of the quarry. 
Petrology of fracture filling minerals in the granite and diagenetic minerals cementing the overlying arkoses provide evidence of common cementation stages, strongly suggesting fluid circulation between the two lithological compartments. A first common stage is microquartz and illite, followed by coarser quartz (euhedral in granite, xenomorphic in arkose) \pm barite. Illite formation indicates temperatures of at least $\sim 130-150^{\circ} \mathrm{C}$ (Liewig and Clauer, 2000). Therefore, this cementation stage results from deep circulation of hot fluids associated with high fluid/rock ratios at the cover/granite interface. A second common stage consists of hydroxides with minor clays and microquartz that fill residual porosity in fractures, faults, and breccia corridors in granite and in the arkose matrix. The presence of iron hydroxides trapped in cements filling porosity of plagioclase dissolution in granite testifies to preTriassic granite weathering conducting to the arkose deposition. All these observations highlight three major fluid circulation stages and fluid/rock interactions: (1) pre-Triassic weathering, (2) deep hot fluid circulation at depth (hydrothermal stage), and (3) recent weathering.

The three alteration stages are present in the core zone and damage zone and in granite and arkose, indicating that fluid circulation has been active in all zones since the deposition of arkose, due to preTriassic granite disaggregation and weathering. However, the intensity of each alteration/weathering stage varies in the damage zone and core zone, and with rock type (granite/arkose) in relation to fluid pathways (Figure 1).

\section{Conclusion}

Based on an integrated geological, structural and petrological study at the quarry scale, we propose a conceptual model of the fracture network at the sedimentary cover/basement transition that integrates fluid circulation with geological time (Figure 1).

This model could help the geothermal exploration in the deeper part of the Rhine Graben by identified the main circulation/plugging zones at the transition zone of the crystalline basement and the sedimentary cover.

\section{Acknowledgements}

This study was co-funded by ANR (French National Research Agency) in the framework of the ANR project CANTARE-Alsace (ANR-15-CE06-0014). The authors would like to thank Jérémie De Bonneval, Director of Leonhart for permitting the access of the quarry.

\section{References}

Bauer, J.F., Meier, S., Philipp, S.L., 2015. Architecture, fracture system, mechanical properties and permeability structure of a fault zone in Lower Triassic sandstone, Upper Rhine Graben. Tectonophysics 647-648, 132-145.

Kushnir, A.R.L., Heap, M.J., Baud, P., Gilg, H.A., Reuschlé, T., Lerouge, C., Dezayes, C., Duringer, P., 2018. Characterizing the physical properties of rocks from the Paleozoic to Permo-Triassic transition in the Upper Rhine Graben. Geothermal Energy 6, 16.

Liewig, N., Clauer, N., 2000. K-Ar dating of varied microtextural illite in Permian gas reservoirs, northern Germany. Clay Minerals 35, 271-281. 